\title{
Controlling Mature Ashe Juniper in Texas with Crown Fires
}

F.C. BRYANT, G.K. LAUNCHBAUGH, AND B.H. KOERTH

\section{Abstract}

Dozed plots and windrow plots were evaluated during 1979 and 1980 with respect to their effectiveness in igniting a crown fire in an adjacent live juniper stand. Dozed plots were ineffective in igniting a crown fire. However, if herbaceous fuel is less than $500 \mathrm{~kg} / \mathrm{ha}$, windspeed is less than $10 \mathrm{~km} / \mathrm{hr}$, humidity is above $45 \%$ and air temperature is less than $30^{\circ} \mathrm{C}$, recently chained or dozed juniper (<100 days since treatment) can be burned with minimal risks. Windrowed plots produced the best results for igniting the adjacent crowns. Correlation coefficients and coefficients of determination indicated that air temperature, maximum windspeed, and leaf moisture would best predict the area the fire would burn per 6 $m$ of windrow length. Crown fires usually stopped where distance between trees exceeded 7 to $10 \mathrm{~m}$. For optimum results, average windspeed should exceed $16 \mathrm{~km} / \mathrm{hr}$, canopy cover should exceed $35 \%$, relative humidity should be between 20 and $40 \%$, air temperature should be between 2 and $32^{\circ} \mathrm{C}$, and leaf moisture should be below $60 \%$. Although potential for broad application is limited, this technique could reduce the total cost of juniper control or could be used in wildlife habitat management.

Ashe juniper (Juniperus ashei), a non-sprouting species, is a major brush problem on the Edwards Plateau region of Texas (Wink and Wright 1973, Wright 1978) because it suppresses growth of understory herbaceous vegetation and lowers forage availability to domestic livestock and wildlife. The economical control of mature stands has become an increasing concern to rangeland managers. Costs of total chemical or mechanical treatment of stands of woody plants are becoming prohibitive.

Prescribed burning can control small Ashe juniper if a minimum of $1,123 \mathrm{~kg} / \mathrm{ha}$ of fine fuel is available (Wink and Wright 1973). With windspeed of $16 \mathrm{~km} / \mathrm{h}$, air temperature of $23^{\circ} \mathrm{C}$, and relative humidity of $28 \%$, almost all trees less than $1.8 \mathrm{~m}$ tall were killed. Under cooler burning conditions in Oklahoma, Dalrymple (1969) obtained $100 \%$ kill of trees less than $0.6 \mathrm{~m}$ and $1.8 \mathrm{~m}$. However for trees over $1.8 \mathrm{~m}$ tall in Oklahoma, less than $25 \%$ were killed by fire. Other researchers also have reported this inverse relationship between tree size and mortality due to fire (Dwyer and Pieper 1967).

While burning of individual trees has been used to control mature juniper (Arnold et al. 1964, Jameson 1966), only Sch roeder (1966) and Bruner and Klebenow (1979) have attempted crown fires in pinyon (Pinus edulis) and juniper (Juniperus sp.) woodlands. Schroeder (1966) predicted that a nearly pure stand of juniper would be impossible to burn and suggested that there is a positive relationship between the percentage of pinyon in the stand and the success of fire spread. Bruner and Klebenow (1979) recommended that canopy cover must be at least $23-35 \%$ for a successful

The authors were assistant professor, research assistant, and research associate, Department of Range and Wildlife Management, Texas Tech University, Lubbock 79409. Launchbaugh currently is with the Texas Agricultural Experiment Station, Uvalde, while Koerth is with the Texas Agricultural Experiment Station, Corpus Christi. We are indebted to Charles Schriener IV of the YO Ranch for financial and logistical support. We also thank Dr. Henry A. Wright for his help throughout the study, and especially his helpful criticism of the manuscript. Support from the Noxious Brush and Weed Control Program, Texas Tech University, is gratefully acknowledged. Technical Article T-9-269 from the College of Agricultural Sciences, Texas Tech University.

Manuscript received July 29, 1981. burn in Nevada. They advised against burning closed stands (>35\% canopy cover of trees) because the fire might be difficult to control and understory shrubs would need to be present to carry the fire.

In certain areas of the Edwards Plateau, several problems arise that have before precluded the use of prescribed burning: (1) the mature age class of a stand that supports trees 1.8 to $4.6 \mathrm{~m}$ in height, (2) the lack of fine fuel or understory sh rubs to carry a fire, and (3) the fear of hazardous conditions necessary to carry a fire. Another salient limitation was that crown fires may not allow for site selection and treatment control without dozed firelines (Aro 1971).

The objectives of this study were to evaluate prescribed burning in dense stands of tall mature juniper trees which lacked a continuous understory of herbaceous or shrubby vegetation and to establish the conditions necessary for a successful burn without the need for dozed firelines.

\section{Study Area and Methods}

Approximately 250-ha of a dense Ashe juniper community with very little understory was selected on the YO Ranch, $48 \mathrm{~km} \mathrm{SE}$ of Junction, Texas, on the Edwards Plateau. The Edwards Plateau of west-central Texas covers about $1 \times 10^{7}$ ha of rangeland (Auken et al. 1980). The Plateau boundaries on the south and east were formed by the Balconies Escarpment, but on the north and west, they blend with the Rolling Plains and Trans-Pecos regions, respectively (Gould 1969). Across the Edwards Plateau from east to west, rainfall varies from 84 to $38 \mathrm{~cm} / \mathrm{yr}$. Peaks in rainfall occur in April and May and again in September or October. Mean annual treatment is $20^{\circ} \mathrm{C}$. Soils usually are shallow, underlain by caliche or limestone (Gould 1969).

The study site was classified as a low, stoney hill range site with Tarrant stoney clay soils. Ashe juniper dominated the vegetation. Plateau oak (Quercus virginianus var fusiformes), Vasey shin oak (Q. vaseyana), and Texas persimmon (Diospyros texana) also were common woody plants. Grass species included Texas grama (Bouteloua texana), threeawn (Aristida sp.), curly mesquite (Hilaria berlangeri), and occasionally little bluestem (Schizachyrium scoparium).

In June 1978, a fireline $61 \mathrm{~m}$ wide was established in a horseshoe fashion on the north, east, and west sides of the 250-ha study site. The fireline was cleaned by pushing trees into piles in the middle of the fireline. These piles were burned in June 1978. This insured that a crown fire could be contained if strong, southerly winds occurred during ignition. Color infra-red photographs $(1: 4,800)$ were used to select sites of varying canopy cover among plots to be burned, since cover was an important criterion in evaluating the success of crown fires in Nevada (Bruner and Klebenow 1979).

Thirty-five plots, $30 \times 15 \mathrm{~m}$, were dozed in February 1979. Ashe juniper trees were pushed down, thus increasing the quantity of ground-level fuel. This was done to allow the fire front to gather intensity prior to entry into the adjacent standing juniper. In the summer of 1979, 20 additional plots were dozed into windrows adjacent to live standing trees. This allowed ignition of an intense 


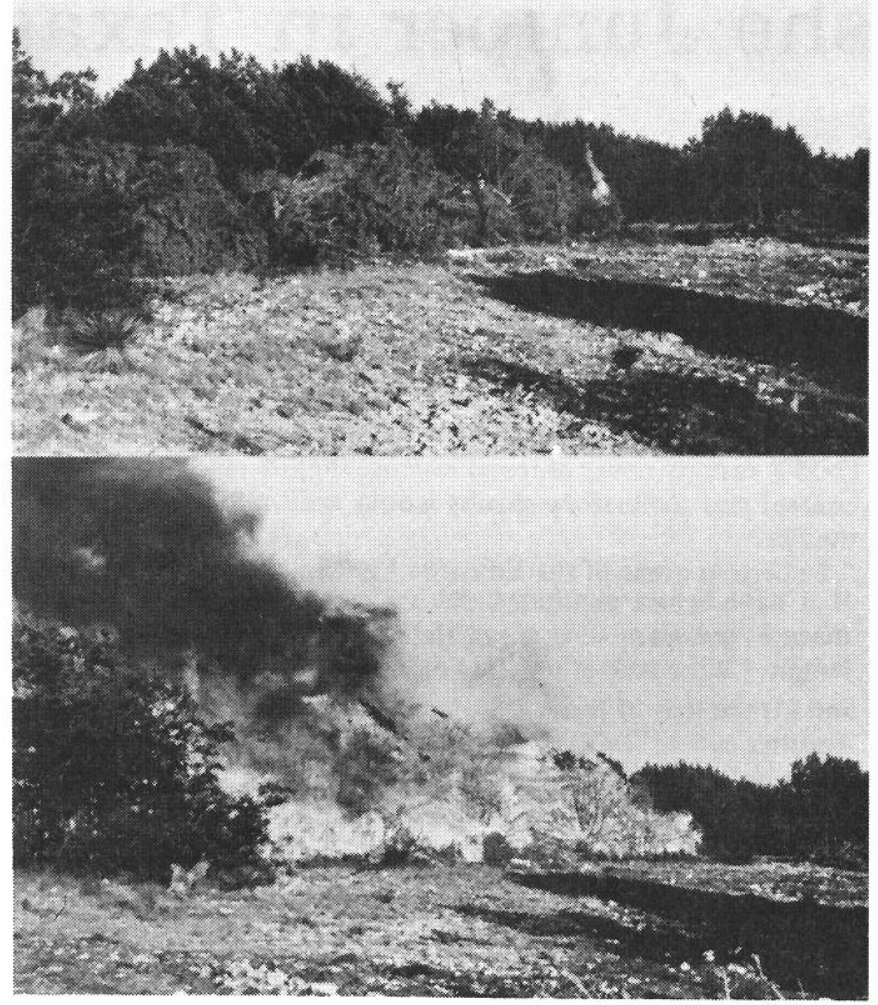

Fig. 1. Windrows used to ignite dense stands of live Ashe juniper on the Edwards Plateau of Texas.

fire with flames in contact with standing trees (Schroeder 1966). Windrowed plots ranged from $30 \mathrm{~m}$ to $79 \mathrm{~m}$ in length. After allowing at least 60 days for the leaves to dry, plots were burned in June and October 1979, and March, April, and May 1980.

Efficacy of burns was evaluated using correlation matrices and simple and multiple regressions (Barr et al. 1976) with total area burned $/ 6 \mathrm{~m}$ of windrow as a dependent variable. This allowed a quantative evaluation of all windrows irrespective of their length. Independent variables included ambient air temperature $\left({ }^{\circ} \mathrm{C}\right)$, average wind speed $(\mathrm{km} / \mathrm{h})$, maximum wind speed $(\mathrm{km} / \mathrm{h})$, relative humidity (\%), canopy cover (\%), juniper density (plants/ha), and juniper leaf moisture $(\%)$. All weather parameters were measured immediately before ignition of either the dozed or windrowed plots. A sling psychrometer was used to determine ambient air temperature and relative humidity; wind speeds (both average and maximum) were measured with a hand-held wind gauge. Windspeeds also were measured while the crown was burning. Percent canopy cover was measured with a photogrid from the color infra-red imagery, on the area immediately adjacent to and leeward of each established plot. Although canopies of live oak and shin oak were included, their contribution to the total canopy cover estimate was minimal. At least 150 grams of live juniper leaves were harvested and weighed immediately prior to ignition. The samples were subsequently air-dried in a forced-air oven at $60^{\circ} \mathrm{C}$ and weighed. Percent moisture content was calculated as the difference between fresh and dry weights, divided by dry weight.

\section{Results and Discussion}

\section{Dozed Plots}

Dozed plots proved ineffective in igniting the live, standing juniper. Although 35 plots were dozed, it was obvious after burning 11 that this treatment was a futile exercise. Further attempts to ignite standing, live juniper using dozed plots were abandoned. Although burning dozed plots failed to achieve our objectives the results have important management implications. $\mathrm{Bu}$ ing recently chained or dozed juniper can be done with minimal $\mathrm{r} . \mathrm{K}$ of igniting the adjacent standing juniper if herbaceous fuel is less than $500 \mathrm{~kg} / \mathrm{ha}$, windspeed is less than $10 \mathrm{~km} / \mathrm{hr}$, humidity is above $45 \%$, and air temperature is below $30^{\circ} \mathrm{C}$. This recommendation was based on the range of values (temperature $26-33^{\circ} \mathrm{C}$, windspeed 3-18 $\mathrm{km} / \mathrm{hr}$, humidity $30-55 \%$, biomass $26-720 \mathrm{~kg} / \mathrm{ha})$ we obtained. Recently dozed or chained juniper $(<100$ days since treatment) should be burned when grass is green to circumvent the possibility of grass fires. This timing usually corresponds with May or June on the Edwards Plateau.

\section{Windrowed Plots}

Windrowed plots were most effective in burning standing, green juniper (Table 1). A correlation matrix (Table 2) indicated that area burned $/ 6 \mathrm{~m}$ of windrow was positively correlated $(P<0.05)$ with average windspeed and maximum windspeed and negatively correlated with humidity and canopy cover. Results from average and maximum windspeed and humidity were expected i.e., more total area burned with higher winds and lower humidities. The significant negative correlation with canopy cover was unexpected, especially since canopy cover was so important in Bruner and

Table 1. Burn results and environmental and physical conditions for burns on windrowed plots on the YO Ranch during 1979 and 1980.

\begin{tabular}{|c|c|c|c|c|c|c|c|c|c|c|}
\hline Date & Plot & $\begin{array}{l}\text { Area } \\
\text { burned/ } \\
6 \mathrm{~m} \text { wind- } \\
\text { row }\left(\mathrm{m}^{2}\right)\end{array}$ & $\begin{array}{c}\text { Canopy } \\
\text { cover } \\
(\%)\end{array}$ & $\begin{array}{c}\text { Juniper } \\
\text { density } \\
\text { (plants/ } \\
\text { ha) }\end{array}$ & $\begin{array}{l}\text { Windrow } \\
\text { length } \\
(\mathrm{m})\end{array}$ & $\begin{array}{c}\text { Tempera- } \\
\text { ture } \\
\left({ }^{\circ} \mathrm{C}\right)\end{array}$ & $\begin{array}{l}\text { Average } \\
\text { wind- } \\
\text { speed } \\
(\mathrm{km} / \mathrm{h})\end{array}$ & $\begin{array}{l}\text { Maximum } \\
\text { wind- } \\
\text { speed } \\
(\mathrm{km} / \mathrm{h})\end{array}$ & $\begin{array}{c}\text { Humidity } \\
(\%)\end{array}$ & $\begin{array}{c}\text { Leaf } \\
\text { moisture } \\
(\%)\end{array}$ \\
\hline June 1979 & 39 & 124 & 49 & 576 & 30 & 32 & 11.3 & 19.3 & 39 & 80 \\
\hline June 1979 & 38 & 142 & 54 & 786 & 30 & 32 & 14.5 & 19.3 & 34 & 78 \\
\hline June 1979 & 37 & 112 & 46 & 477 & 30 & 27 & 8.0 & 14.5 & 45 & 77 \\
\hline Oct. 1979 & 40 & 215 & 54 & 558 & 30 & 34 & 9.7 & 16.1 & 28 & 69 \\
\hline Oct. 1979 & 41 & 244 & 54 & 462 & 30 & 35 & 9.7 & 16.1 & 27 & 59 \\
\hline Oct. 1979 & 42 & 227 & 54 & 512 & 30 & 32 & 9.7 & 12.9 & 32 & 59 \\
\hline Oct. 1979 & $6 \mathrm{~A}$ & 143 & 55 & 731 & 49 & 26 & 9.7 & 12.9 & 40 & 60 \\
\hline Oct. 1979 & $6 \mathrm{~B}$ & 161 & 55 & 670 & 49 & 26 & 9.7 & 12.9 & 40 & 57 \\
\hline Mar. 1980 & 2 & 230 & 35 & 554 & 64 & 23 & 12.9 & 32.2 & 38 & 60 \\
\hline Mar. 1980 & 28 & 144 & 46 & 576 & 43 & 23 & 9.7 & 16.1 & 41 & 59 \\
\hline Mar. 1980 & $25 \mathrm{~A}$ & 307 & 38 & 702 & 30 & 22 & 8.0 & 19.3 & 40 & 59 \\
\hline Mar. 1980 & $25 B$ & 214 & 38 & 712 & 30 & 22 & 8.0 & 19.3 & 40 & 59 \\
\hline Mar. 1980 & 24 & 305 & 37 & 623 & 61 & 29 & 12.9 & 19.3 & 27 & 59 \\
\hline Apr. 1980 & $5 \mathrm{~A}$ & 468 & 40 & 749 & 73 & 32 & 32.2 & 40.2 & 20 & 60 \\
\hline Apr. 1980 & $5 \mathrm{~B}$ & 399 & 40 & 613 & 79 & 32 & 32.2 & 40.2 & 20 & 59 \\
\hline May 1980 & 29 & 176 & 39 & 665 & 43 & 26 & 8.0 & 14.5 & 68 & 60 \\
\hline May 1980 & $27 \mathrm{~A}$ & 198 & 43 & 813 & 73 & 31 & 11.3 & 25.7 & 51 & 69 \\
\hline May 1980 & $27 \mathrm{~B}$ & 284 & 43 & 815 & 73 & 31 & 11.3 & 25.7 & 51 & 69 \\
\hline
\end{tabular}


Table 2. Correlation matrix of dependent and independent variables for juniper burns on the YO Ranch near Junction, Texas.

\begin{tabular}{|c|c|c|c|c|c|c|c|c|}
\hline & $\begin{array}{c}\text { Area } \\
\text { burned }\end{array}$ & $\begin{array}{l}\text { Canopy } \\
\text { cover }\end{array}$ & $\begin{array}{c}\text { Air } \\
\text { temperature }\end{array}$ & $\begin{array}{l}\text { Average } \\
\text { windspeed }\end{array}$ & $\begin{array}{l}\text { Maximum } \\
\text { windspeed }\end{array}$ & Humidity & $\begin{array}{c}\text { Leaf } \\
\text { moisture }\end{array}$ & $\begin{array}{l}\text { Juniper } \\
\text { density }\end{array}$ \\
\hline Area burned & & $\begin{array}{c}-0.491 \\
(0.04)^{2}\end{array}$ & $\begin{array}{c}0.19 \\
(0.43)\end{array}$ & $\begin{array}{c}0.77 \\
(0.01)\end{array}$ & $\begin{array}{l}-0.77 \\
(0.01)\end{array}$ & $\begin{array}{l}-0.55 \\
(0.02)\end{array}$ & $\begin{array}{l}-0.44 \\
(0.07)\end{array}$ & $\begin{array}{c}0.19 \\
(0.45)\end{array}$ \\
\hline Canopy cover & & & $\begin{array}{c}0.48 \\
(0.04)\end{array}$ & $\begin{array}{l}-0.27 \\
(0.29)\end{array}$ & $\begin{array}{l}-0.56 \\
(0.01)\end{array}$ & $\begin{array}{l}-0.15 \\
(0.56)\end{array}$ & $\begin{array}{c}0.23 \\
(0.35)\end{array}$ & $\begin{array}{l}-0.19 \\
(0.43)\end{array}$ \\
\hline Air temperature & & & & $\begin{array}{c}0.33 \\
(0.19)\end{array}$ & $\begin{array}{c}0.13 \\
(0.61)\end{array}$ & $\begin{array}{l}-0.39 \\
(0.10)\end{array}$ & $\begin{array}{c}0.34 \\
(0.17)\end{array}$ & $\begin{array}{l}-0.08 \\
(0.74)\end{array}$ \\
\hline Average windspeed & & & & & $\begin{array}{c}0.86 \\
(0.01)\end{array}$ & $\begin{array}{l}-0.60 \\
(0.01)\end{array}$ & $\begin{array}{l}-0.09 \\
(0.73)\end{array}$ & $\begin{array}{c}0.18 \\
(0.48)\end{array}$ \\
\hline Maximum windspeed & & & & & & $\begin{array}{l}-0.39 \\
(0.10)\end{array}$ & $\begin{array}{l}-0.06 \\
(0.81)\end{array}$ & $\begin{array}{c}0.27 \\
(0.27)\end{array}$ \\
\hline Humidity & & & & & & & $\begin{array}{c}0.16 \\
(0.53)\end{array}$ & $\begin{array}{c}0.27 \\
(0.27)\end{array}$ \\
\hline Leaf moisture & & & & & & & & $\begin{array}{c}0.04 \\
(0.86)\end{array}$ \\
\hline Juniper density & & & & & & & & \\
\hline
\end{tabular}

'Correlation coefficient

2Probability > 'RHO', $\mathrm{H}_{\mathrm{o}}: \mathrm{RHO}=0$

Klebenow's (1979) study. Our total canopy cover estimates varied from 35 to $55 \%$ (Table 1). These ranges in canopy cover must have been at or above the threshold where canopy cover ceases to become a viable criteria for evaluating burns of this nature. Density of juniper trees in the burned area gave a positive correlation, but it was non-significant $(P>0.45)$. Still, density of juniper may provide a more realistic criterion for evaluating burns in dense juniper stands than total canopy cover. In predicting the area one could burn per $6 \mathrm{~m}$ of windrow, a stepwise maximum $R$-square improvement model (Barr ct al. 1976) indicated maximum windspeed and leaf moisture was the best 2-variable model (Table 3), whereas the best 3-variable model included maximum windspeed, air temperature, and leaf moisture (Table 3 ). Although humidity and canopy cover were significantly correlated with area burned in the matrix, neither variable was included by the stepwise, maximum $R^{2}$ improvement model because both variables exceeded the 0.05 level of significance when entered. This may have been due to the high correlation $(P<0.05)$ of humidity with average wind speed and canopy cover with maximum windspeed (Table 1).

Where the fire stops is also important. From our observations of crown fire behavior under the conditions of our burns, we felt that the primary factor limiting fire spread was the distance from the last tree that burned to the nearest unburned/unscorched live juniper. This distance averaged across all burns exceeded $8.0 \mathrm{~m}$ (range 4.6 to $13.6 \mathrm{~m}$ ).

\section{Summary and Conclusions}

Correlation coefficients and regressions indicated windspeed (average and maximum) and leaf moisture were the 2 most impor-

Table 3. Regression equations and $\boldsymbol{R}^{2}$ of 2-variable and 3-variable regressions using area burned/ $6 \mathrm{~m}$ of windrow as the dependent variable.

\begin{tabular}{lll}
\hline \hline Independent variables & Equation & $\begin{array}{c}\text { Coefficient of } \\
\text { determination' } \\
\left(R^{2}\right)\end{array}$ \\
\hline $\begin{array}{c}\text { Average wind speed }\left(x_{1}\right)+ \\
\quad \text { leaf moisture }\left(x_{2}\right)\end{array}$ & $y=600+9.6 x_{1}-12.7 x_{2}$ & 0.73 \\
$\begin{array}{c}\text { Maximum windspeed }\left(x_{1}\right)+ \\
\text { leaf moisture }\left(x_{2}\right)\end{array}$ & $y=576+8.2 x_{1}-13.4 x_{2}$ & 0.74 \\
$\begin{array}{c}\text { Maximum windspeed }\left(x_{1}\right)+ \\
\text { air temperature }\left(x_{2}\right)+ \\
\text { leaf moisture }\left(x_{3}\right)\end{array}$ & $\begin{array}{l}y=530+7.8 x_{1}+6.3 x_{2}- \\
16.6 x_{3}\end{array}$ & 0.80 \\
\hline
\end{tabular}

1prob $>F=0.0001$ tant variables for achieving a satisfactory burn. Thus early spring (March or April) in central Texas would be the optimum time to burn because winds are higher and leaf moisture is lower.

Windrows are highly recommended over dozing in order to ignite a crown fire. The following environmental conditions should be observed: (1) canopy cover $>35 \%$ or juniper density $>500$ plant/ha, (2) windspeeds $>16 \mathrm{~km} / \mathrm{h}$, (3) air temperature 23 to $33^{\circ} \mathrm{C}$, (4) relative humidity $20-35 \%$ and (5) juniper leaf moisture $58-60 \%$.

A firebreak would not be necessary if the fire was carefully planned. First, heavy stocking of livestock within a $2.0-\mathrm{km}$ radius of the burn for a short, 2-month period prior to burning would be a precaution to prevent grass fires if fine fuel exceeded $561 \mathrm{~kg} / \mathrm{ha}$. Livestock should be stocked heavy enough to insure reduction of fine fuels and the pasture must be rested at least 1-yr following the burn. Second, our data indicated the fire would not spread from tree to tree as long as the distance between trees was $8.0 \mathrm{~m}$ or more. Thus, the burn must be planned so that the crown fire would carry into less dense juniper.

Although this technique has limited application because high winds, "hot" conditions, and dense juniper are requisite, it may have application in wildlife habitat management to "open up" dense, stagnant stands of juniper. This is especially true where live oak or shin oak occur and burning encourages resprouting of nutritious leaves and stems. Further, for brush control, our ratio of total number of junipers dozed into the windrow:total number of junipers killed varied from 1:2.3 to 1:9.4 with an average of 1:5.4. This means that for every juniper that is wind rowed, the applicator can expect to kill an average of about 6 trees for a net savings in costs of mechanical treatment.

Recently chained or dozed juniper ( $<100$ days since treatment) can be safely burned in May or June if grass is green. Fine fuels should be less than $500 \mathrm{~kg} / \mathrm{ha}$, windspeed should be less than 10 $\mathrm{km} / \mathrm{hr}$, humidity should be above $45 \%$, and air temperature should be below $30^{\circ} \mathrm{C}$.

\section{Literature Cited}

Aro, A.S. 1971. Evaluation of pinyon-juniper conversion to grassland. J. Range Manage. 24:188-197.

Arnold, J.F., D.A. Jameson, and E.H. Reid. 1964. The pinyon-juniper type of Arizona: Effect of grazing, fire, and tree control. USDA Production Res. Rep. No. 84.

Auken, 0.W., A.L. Ford, A. Stein, and A.G. Stein. 1980. Woody vegetation of upland plant communities in the southem Edwards Plateau. Tex. J. of Sci. 32:23-35. 
Barr, A.J., J.H. Goodnight, J.S. Sall, and J.T. Helwig. 1976. A user's guide to S.A.S. 76. SAS Institute Inc. Raleigh. N.C. 329 p.

Bruner, A.D., and D.A. Klebenow. 1979. Predicting success of prescribed fires in pinyon-juniper woodland in Nevada. U.S. Forest Serv. Intermountain Forest and Range Exp. Sta. Res. paper 219.

Dalrymple, R.L. 1969. Prescribed grass burning for Ashe juniper control. Prog. Rep. from Noble Foundation, Inc. Ardmore, Okla. 73401.

Dwyer, D., and R.D. Pieper. 1967. Fire effects of blue grama-pinyonjuniper rangeland in New Mexico. J. Range Manage. 20:359-362.

Gould, F.W. 1969. Texas plants-a checklist and ecological summary. Tex. Agr. Exp. Bull. MP-585.
Jameson, D.A. 1966. Juniper control by individual tree burning. U.S. Forest Serv., Rocky Mountain Forest and Range Exp. Sta. Res. Note. 71.

Schroeder, W.L. 1966. Guidelines for control burning in pinyon-juniper woodlands on the Hualapai Reservation. USDI Bureau of Indian Affairs. Mimeo.

Wink, R.L., and H.A. Wright. 1973. Effects of fire on an Ashe juniper community. J. Range Management 26:326-329.

Wright, H.A. 1978. Use of fire to manage grasslands of the Great Plains: Central and Southern Great Plains. In: Proc. First Internat. Rangeland Cong. p. 694-696. 